\title{
A new treatment modality in piriformis syndrome: Ultrasound guided dry needling treatment
}

\author{
Piriformis sendromunda yeni bir tedavi modalitesi: Ultrason rehberliğinde kuru \\ iğneleme tedavisi
}

(1) Fatih BAĞCIER, ${ }^{\circledR}$ ( Fatih Hakan TUFANOĞLU²

To the Editor,

The article titled, "Reflex sympathetic dystrophy secondary to piriformis syndrome: a case report."[1] Published in April 2009, while discussing the treatments for piriformis syndrome in the article, ultrasound-guided dry needling (DN) treatment was not mentioned. DN treatment, as being more popular recently, has become a part of our practices.

A 54-year-old male patient was admitted to the clinic with the complaints of pain, numbness and tingling, which the patient had been experiencing for the last 1 year, at the waist and spreading behind the buttocks and thighs. The patient's pain was mechanical and increased if standing and sitting for a long time and decreased with resting in lying position. He had no known history of trauma and on physical examination, he did not have any paravertebral muscle spasm in the lumbar region. No trochanter major and interspinal distance sensitivity was detected. Faber and Fadir tests that evaluate sacroiliac and hip joint were bilateral negative. There was sensitization with deep palpation in the right gluteal region. Frieiberg and Pace tests were positive on the side having pain. Visual analogue scale (VAS) value was 7 out of 10. Oswestry disability index (ODI) score was 78 . Magnetic resonance imaging of the hip region was requested for the exclusion of other possible pathologies with a preliminary diagnosis of piriformis syndrome (PS).

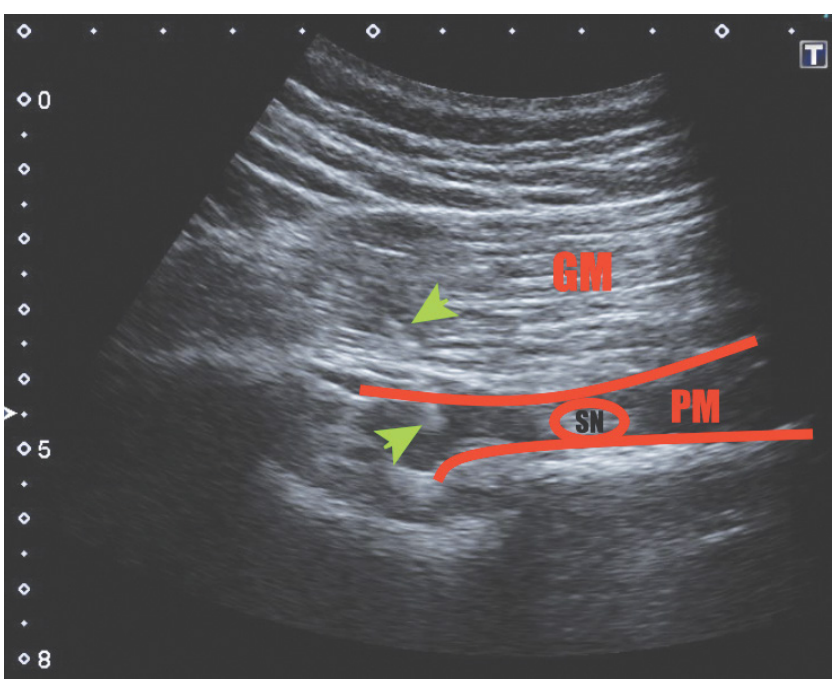

Figure 1. Ultrasound guided dry needling treatment of piriformis syndrome.

No pathology was detected, and the patient was diagnosed with PS. Prior to medical treatment (myorelaxant, non-steroidal anti-inflammatory, pregabalin), the patient was planned to receive ultrasoundguided DN (Fig. 1). In addition, stretching exercises for piriformis muscle were recommended. DN was performed one session per week, 3 times in total. Pregabalin treatment was started for neuropathic pain. In the first month of the treatment, a follow-up examination was performed. The patient's VAS value decreased to $2 / 10$ and ODI score decreased to 35 .

PS is the cause of non-discogenic sciatica caused by compression of the sciatic nerve under piriformis

\footnotetext{
'Departmant of Physical Medicine and Rehabilitation, Kars Harakani State Hospital, Kars, Turkey ${ }^{2}$ Department of Radiology, Sarıkamış State Hospital, Kars, Turkey

Submitted: 04.05.2019 Accepted after revision: 18.11.2019 Available online date: 04.06.2020

Correspondence: Dr. Fatih Bağcıer. Kars Harakani Devlet Hastanesi, Fiziksel Tıp ve Rehabilitasyon Kliniği, 36100 Kars, Turkey. Phone: +90 - 544 - 2429042 e-mail: bagcier_42@hotmail.com

(c) 2020 Turkish Society of Algology
} 
muscle for structural or acquired reasons. Myofascial trigger points (MTrP) are the most common ones in its etiology, and there are anatomical variations of the hypertrophy, inflammation, trauma, piriformis muscle or sciatic nerve in its muscle tissue. ${ }^{[2]}$ Conservative approaches such as lifestyle changes, medical therapy, physical therapy modalities and exercise therapy are generally successful in its treatment. In patients with resistance, interventional procedures (such as dry needling, steroid-local anesthetic injection) may be applied. DN treatment is a treatment method where MTrPs are stimulated using acupuncture needles or injection needles..$^{[3]}$ It can be performed according to anatomical indicators, as well as with ultrasound and fluoroscopy. It can also be performed with blinding, but the success probability of reaching the right region with this method is low compared to the ultrasound-guided DN. Besides, there is a risk of damaging neighboring neurovascular structures. Finnoff et al. ${ }^{[4]}$ compared ultrasound and fluoroscopy as a guide for PS injection in their study. They found the success rate of ultrasound to be $95 \%$ and fluoroscopy to be $35 \%$. Fusco et al. ${ }^{[5]}$ administered ultrasound-guided dry needling treatment to three patients with piriformis syndrome and obtained improvement in pain and functionality parameters. Our approach is different from this study in two aspects. Fusco et al. ${ }^{[5]}$ administered an average of 8 sessions of DN treatment to 3 patients in 10 days. The size of the needle they used was $0.30 \times 60$ $\mathrm{mm}$. In our study, we performed 3 sessions with one- week interval and used a thicker needle with a size of $0.60 \times 60 \mathrm{~mm}$. There is no clear treatment frequency for DN in the literature. We think that our practice is less invasive, more cost-effective and an approach that improves patient compliance.

In conclusion, DN should be included in our treatment modalities as a microinvasive, inexpensive and effective method in the treatment of PS. With the use of ultrasound, which is called as "my extended hand", "my sixth finger", "complementary examination" by the physicians in clinical practice, its success will increase.

\section{References}

1. Akçali $D$, Taş $A$, Cizmeci $P$, Oktar $S$, Zinnuroğlu M, Arslan E, Köseoğlu H, Babacan A. Reflex sympathetic dystrophy secondary to piriformis syndrome: a case report. Agri 2009;21(2):75-9.

2. Külcü DG, Mesci N, Batıbay SC, Taraktaş, Aktaş İ. Evaluation of Short-term Effectiveness of Ultrasound-guided Injection in Treatment of Piriformis Syndrome. Bosphorus Med J 2017;4(1):4-7.

3. Akkurt S. Kuru Iğneleme. Turkiye Klinikleri Journal of Sports Medicine-Special Topics 2018;4(1):56-9.

4. Finnoff JT, Hurdle MF, Smith J. Accuracy of ultrasoundguided versus fluoroscopically guided contrast-controlled piriformis injections: a cadaveric study. J Ultrasound Med 2008;27(8):1157-63. [CrossRef]

5. Fusco P, Di Carlo S, Scimia P, Degan G, Petrucci E, Marinangeli F. Ultrasound-guided Dry Needling Treatment of Myofascial Trigger Points for Piriformis Syndrome Management: A Case Series. J Chiropr Med 2018;17(3):198-200. 